\title{
Psychological Effects of Marawi Siege on the Academic Performance in Science of MSU-UTC Students
}

\author{
Emily V. Diampon \\ Mindanao State University, Marawi City, Lanaodel Sur \\ Wenceslao A. Coronado, Bella C. Mugot, Sylvia C. Labial and Flordelina A. Cadeliňa \\ Mindanao State University, Naawan, Misamis Oriental
}

\begin{abstract}
The study was undertaken to find out the psychological effects and performance in science of MSU -University Training Centre grade 10 students after the siege happened in Marawi City. Specifically, the study sought to answer the following questions; (1) what is the psychological status of the students after the Marawi siege regarding anxiety and stress manifestation? (2) Is there a significant relationship between the psychological status and the academic performance in science of the MSUUTC students brought about by the Marawi siege? The research study used quasi experimental with qualitative research design. A population of eighty-two (82) grade 10 students were used in the conduct of the study. The following results showed that (1) students have more worries now than before the Marawi siege ; (2) Students feel pressured because of the many requirements in school; (3) Performance of students in science and Psychological stress are not associated without psychosocial intervention or values integration; (4) While with psychosocial intervention student performance and stress are significantly related; (5) and lastly, students anxiety and performance in science both with and without psychosocial intervention are not significantly related.
\end{abstract}

Keywords: academic performance, anxiety, Marawi siege, psychological status, stress, values integration.

\section{Introduction}

Marawi City is popularly known as the "Islamic City" of Marawi. It is the capital city in Lanaodel Sur comprising of 87.55 square kilometres of high elevated land, subdivided into 96 barangays. Based on the 2015 census, it is the most populous area in the province of Lanao del Sur consisting of 201,785 residents of which majority of the population are Muslims. The city is considered as the commercial, religious, educational, cultural, and political centre of the province. Their economy depends primarily on rice and corn agriculture, the export of various crafts such as wood, and malong, and most of the Maranao people are engaged in small-scale and large businesses (PSA, 2015).

The conflict or the battle of Marawi, more popularly known as the" Marawi siege" became the centre stage of the whole world's attention when the densely populated and progressive small city in Southern Philippines was attacked by its home grown ISISL-inspired terrorist group headed by the Maute brothers.

On May 23, 2017, the unsuspecting people of the Islamic City of Marawi woke up staring eye to eye with horrifying devils of war and destruction. Thousands of Maranao families and other non-Muslims inhabitants scampered away from the city and nearby communities in an epic exodus to escape being trapped in the escalating atrocities between the rebel terrorists and government forces. Philippine President Rodrigo R. Duterte declared Martial law in Mindanao on the same date, following the fire fight between the government military forces and the Maute group militants (Gita, 2017). The five (5) months of heavy combat caused the death of many people, the displacement of 
many teachers and students who lived in the city, the destruction of businesses, public infrastructures, burnt school buildings, houses as well as government facilities. Resulting in large part of Marawi turned into debris.

The Marawi siege completely impacted the many lives of Marawi residents, most especially the lives of displaced elementary and high school learners. According to Gottesman (2016), developing countries' educational systems, in particular, suffer negative effect due to the violent conflicts between military forces and insurgents. The MSU-University Training Centre (MSU-UTC), a largely populated secondary school within the Mindanao State University campus, is one of the affected schools, resulting to a decrease in the students' population because of displaced residential houses and livelihood activities. Truthfully, the psychological effects of the siege are vast, and children are the most affected.

In this light, it is indeed a noble responsibility of the teachers to integrate psychosocial intervention in the classroom were displaced learners recuperate from the anxieties and worries brought by the Marawi siege. Teachers of all displaced learners now play a meaningful role in bringing effective learning process and intervention to all students who are psychologically affected and economically devastated by the siege. Considering that stress and anxiety impact the learning behavior of every child, the teachers' priority must be able to enhance the academic success of the students amidst the adverse psychological and other individual factors.

The researcher tried to identify in this study, the academic performance, and psychological conditions of the grade ten (10) MSU-UTC learners before and after the Marawi siege. Moreover, this research study sought to find out the psychological effects of the Marawi siege on the academic performance in the science of the MSU-UTC students.

This study aimed to determine the psychological status of the MSU-UTC students and its effect on the academic performance in science after the Marawi siege. In particular, the study sought to answer the following questions:

1. What is the psychological status of the students after the Marawi siege regarding?

1.1. anxiety and stress manifestation?

1.2. stress?

1.3. anxiety or worry?

2. Is there a significant relationship between the psychological status and the academic performance in science of the MSU-UTC students brought about by the Marawi siege?

\section{Methodology}

The subjects of this study were the grade 10 students enrolled during the school year 2017-2018 at the MSU-University Training Centre (MSU-UTC). Sections were categorized by homogeneous groupings. This research study used a quasi-experimental with qualitative research design .The researcher recorded their performance in science during first to third quarters of the school year 2017-2018 and without psychosocial intervention. The remaining quarterly performance in science of students was also recorded with psychosocial intervention. The quantitative data gathered in this study include the academic performance of the students in science before and after the siege, psychological status of the students using Likert scale; while the qualitative data gathered in this research focused on the journal writing and interview to qualitatively describe the feedbacks or responses of the students after the siege. This study was conducted at the Mindanao State University-University Training Centre (MSU-UTC) Experimental Campus, Barrio Green, Marawi City where the majority of the students are Maranaos.

\section{Results and Discussions}

This chapter presents the data analysis and interprets the data gathered from the grade ten students of the three sections from MSU-UTC. 
Table 1: Mean scores of the psychological status regarding the anxiety and stress manifestations after the Marawi siege

\begin{tabular}{|c|c|c|c|}
\hline $\begin{array}{l}\text { Statements } \\
\text { score }\end{array}$ & Mean & Indicator & Rank \\
\hline $\begin{array}{l}\text { 1. Are you more stressed today than before } \\
\text { The Marawi siege? }\end{array}$ & 2.55 & Moderate & 4 \\
\hline $\begin{array}{l}\text { 2. Do you worry more today than before } \\
\text { Than Marawi siege? }\end{array}$ & 2.71 & High & 1 \\
\hline $\begin{array}{l}\text { 3. Is your life more difficult now than before } \\
\text { The Marawi siege? }\end{array}$ & e 2.67 & High & 2 \\
\hline $\begin{array}{l}\text { 4. Do you have more problems today } \\
\text { than before the Marawi siege? }\end{array}$ & 2.56 & Moderate & 3 \\
\hline $\begin{array}{l}\text { 5. Does your mind easily go blank today } \\
\text { than before the siege? }\end{array}$ & 2.04 & Moderate & 7 \\
\hline $\begin{array}{l}\text { 6. Is your motivation to go to school become } \\
\text { less as a result of the Marawi siege? }\end{array}$ & 1.70 & Low & 9 \\
\hline $\begin{array}{l}\text { 7. Is your life more stressful and more } \\
\text { depressed now than before the siege? }\end{array}$ & 2.35 & Moderate & 5 \\
\hline $\begin{array}{l}\text { 8. Do you suffer from unexplainable worries, } \\
\text { fears, and negative feelings which you did } \\
\text { not suffer before the siege? }\end{array}$ & 2.20 & Moderate & 6 \\
\hline $\begin{array}{l}\text { 9. Do you suffer difficulty to go to sleep now } \\
\text { which did not happen before the siege? }\end{array}$ & w 1.61 & Low & 10 \\
\hline $\begin{array}{l}\text { 10. Do you consider your emotions and } \\
\text { thoughts more unstable and negative today } \\
\text { than before the siege? }\end{array}$ & 1.94 & Low & 8 \\
\hline
\end{tabular}

Data on Table 1 indicates the mean scores of the anxiety and stress manifestations of the students, indicating the level of their psychological status after the siege. It can be observed that item number two (2) saying that the students have more worries now than before the Marawi siege, ranked as number one with a mean score of 2.71 and described as high level. This is further confirmed by the journal responses of the students indicating their fear and worry that the siege might happen again anytime. Student 56: (Naisip ko na baka maulit ang nangyari sa Marawi at minsan naiisip ko na buwag ng maulit) (Sometimes I think that the Marawi war might happen again and I also think that the war should never be repeated]; Student 80: (Minsan bindi ako makastudy ng maayos dabil sa mga maraming balita na may darating ulit na kaguluban) [Sometimes I cannot study because of the rumors that a conflict is going to happen], and Student 5: (May pangamba pa kasi ako na baka maulit yong siege I don't want that it could happen again) [I'm still worried that the siege might happen again and I do not want that].

The students also indicated that they have more problems and stress now than before the Marawi siege, It is further indicated that the students did not indicate any problems sleeping after the siege, and it seems that sleeping is now considered as a form of escape from the anxiety they feel due to the war. The students confirmed this data in their journal writing indicating that they rather sleep early now than study until midnight because of the noise created by the violent war. Student 82: (Noong una nag-aaral ako ng midnight pero ngayon natutulog ako ng maaga if magputukan sila muli at least nakatulog ako) (Before I have been studying until dawn, but now I sleep early because if they start shooting again I will be sleeping]; Student 9:(Parang gusto ko na lang matulog ng matulog kaysa sa mag-aral, bindi katulad dati) Right now it seems that I just want to sleep rather study, unlike before]. Moreover, the motivation of the students in going to school is not reduced when they responded low in statement 6 , asking them if their motivation to go to school is reduced as a result of the siege.

Student 49 indicated in the journal that she is energized upon return to school because during the siege she was able to rest by doing only activities like sleeping, watching TV, and other nonsense things Student 49: (For me, I got energized when I'm performing some school activities because during the siege, the only thing that I did was watching TV, sleeping and some nonsense things only). It is apparent that the students are still motivated to go to school despite the war, as indicated in their journal feedback saying that even when they are scared of the sounds of bombs and pistols, they are motivated to go to school Student 46: (I'm scared because of the bombs and enfilateds/pistol shot I hear every day even though I hear the sound I'm still motivated to finish my junior high school). Although the students responded high in 
items 2 and 3 (indicating that they have more worries, stress, and problems now than before the siege), they still try to cope with the adverse situation by motivating themselves to study better. Students 68: (Da nyan kaaffect na mas mya-motivate ako mag-aral ng mas mabuti) (The war does not affect on me, rather it motivated me to study better]. In their journal, students indicated that the primary problem that their family is experiencing now is not more on their academic performance but the effect of the war on their socio-economic status, expressing that it is harder now to recuperate from their lost livelihood.

Students 67: (Siguro bindi nga naapektuhan yong pag-aaral ko ngunit naapektuban ang hanapbubay ng mga magulang ko) [Maybe it did not affect my studies, both parents work was affected]. These findings imply that the siege carried signs of stress and anxiety to some of the lives of the students; however, surprisingly, most students are still motivated to go to school despite the adverse psychological effects of the siege. This principle is further elaborated by Knudson (2017), saying that the school which promotes the culture of caring becomes the source of strength of the students; so that when the students are stressed at home, the school becomes the place of solace and peace.

Table 2: Mean scores of the psychological status regarding the stress after the Marawi siege

\begin{tabular}{|c|c|c|c|}
\hline Statements & Mean & Indicator & Rank \\
\hline $\begin{array}{l}\text { 1. Do stress or problems make you perform less in } \\
\text { school? }\end{array}$ & 3.33 & Moderate & 4 \\
\hline $\begin{array}{l}\text { 2. Do you feel pressured because of the many } \\
\text { requirements in the school? }\end{array}$ & 4.04 & High & 1 \\
\hline $\begin{array}{l}\text { 3. Do you find it hard to understand the lessons even if } \\
\text { they are easy? }\end{array}$ & 2.66 & Low & 7 \\
\hline 4. Do you easily get fatigued or tired? & 3.34 & Moderate & 3 \\
\hline 5. Are you stressed with your daily responsibilities? & 3.17 & Moderate & 5 \\
\hline 6. Do you find difficulties in going to school? & 2.55 & Low & 9 \\
\hline $\begin{array}{l}\text { 7. Do you feel generally stressed every time you see } \\
\text { soldiers and other paraphernalia? }\end{array}$ & 2.41 & Low & 10 \\
\hline 8. Do you feel stressed every time you leave home? & 2.59 & Low & 8 \\
\hline 9. Do you feel nervous when you hear loud sounds? & 2.93 & Low & 6 \\
\hline $\begin{array}{l}\text { 10. Do you have the fear that there will be another war } \\
\text { that might happen? }\end{array}$ & 3.77 & Moderate & 2 \\
\hline
\end{tabular}

It is shown in Table 2 the mean scores of the students' stress level as part of their psychological status after the war. The highest mean score is item number two (2) which says that they feel pressured because of the many requirements in school. After the Marawi siege, one source of stressors is the overwhelming requirements given by school teachers to students. This is referred to as academic stress, which linked to academic achievement. According to Ader \& Erktin (2002), academic stress occurs under four circumstances; when student do not have the motivation to their tasks; when responsibilities are overwhelming; and when school environment in itself is a stressor; and when the student is disturbed by personal adverse experiences.

This is further confirmed by the students when they elaborated that it is sometimes difficult for them to concentrate on their studies and to memorize lessons because of the trauma they experienced after the siege. Student 11: Hindi ako ngayon masyadong nakakaconcentrate sa pakikinig sa klase dabil nasa isip ko ang nangyari sa Marawi na-traumatized rin ako kapag may mga kunting naririnig na putok, kaya yon medyo nawalan lang ng concentration ang sarili ko) (I'm not very comfortable with listening to the class because I was thinking of what happened to Marawi, I was traumatized as well when there were stunted sounds, so I lost my concentration] and Student 16: (Hindi ako nakaconcentrate, hindi ko mamemorize ang mga dapat o kailangan ko ememorize at madali kong makalimutan ang mga naiisip ko o plano ko) [I can't concentrate, I can't remember the things I should or need to memorize, and I can easily forget my thoughts or plans].

The next ranked stress response is statement number ten (10), which says that the students are afraid that another war or siege might happen again in the future. This feeling of uncertainty is expounded in their journal write-ups such as that indicated in journal statement saying that the siege 
has a great impact on their concentration to study because Student 42: (I always worry what could happen in the future).

In item seven (7), the students indicated that they are not afraid to see soldiers and other war paraphernalia because armed personnel is common to them as part of their culture in times of "rido". It is a Maranao term commonly used to refer to a state of recurring hostilities between families and kinship groups characterized by a series of retaliatory acts of violence carried out to avenge a perceived affront or injustice (Torres, 2014). Based on observations and experiences a typical Maranao would always have guns in their house to protect them from possible attacks of the opposing family. Student 31 indicated that Marawi city is already used to gun-related violence (Ang Marawi sanay sa putukan) [The Marawi is accustomed to shooting].

Table 3: Mean scores of the psychological status regarding anxiety after the Marawi siege

\begin{tabular}{llll}
\hline Statement & Mean & Indicator & Rank \\
\hline 1. Is it hard for you to feel quiet and calm? & 2.59 & Low & 5 \\
2. Do you feel frightened most of the time? & 2.52 & Low & 8 \\
3. Do you feel anxious or worried about a lot of things? & 3.27 & Moderate & 1 \\
4. Do you worry excessively? & 2.56 & Low & 6 \\
$\begin{array}{l}\text { 5. Do you experience trembling and sweating without any valid } \\
\text { reason after the Marawi siege? }\end{array}$ & & & \\
& & & \\
6. Do you have trouble sleeping? & 2.29 & Low & 9 \\
7. Are you afraid to go out without companion? & 2.67 & Low & 4 \\
& 2.90 & Low & 3 \\
8. Are your worries about creating a negative impact on your & & & \\
academic performance? & & & \\
& & & \\
9. Do you easily forget things more nowadays? & 2.93 & Low & 2 \\
& & & \\
10. Do you experience any muscle tension, aches, and body pains & 2.54 & Low & 7 \\
now? & & & \\
\hline
\end{tabular}

It can be observed in Table 3 the mean scores of the psychological status regarding anxiety level of the students. As shown in the table, most students indicated that they feel most anxious about a lot of things (statement 3, ranked as first). However, this anxiety is considered only as moderate. The second anxiety manifestation is statement number 9 indicating that they tend to forget about a lot of things nowadays. This is confirmed by student 29 in a statement saying that the siege caused those anxieties and worries, resulting in forgetfulness and mental block. Students 29: (Malaki ang epekto sa akin ang mga pangyayari at sa academic performance sa science kasi na mental black o na trauma ako sa mga nangyayari, lalo na noong nag-aral ako ulit sa MSU-UTC ay malaki ang pinagbago ng pagaaral lalo na noong first and second grading period ang maliliit ng mga scores) (The siege greatly affected me and my academic performance in science because I got mental block and traumatized of what happened, especially when I was studying at MSU-UTC. I got low scores in the first and second grading period]. Although the students generally worry about a lot of unspecified things, they indicated that the source of their worry is the anxious thought that maybe the war or the siege is going to happen again.

As student 41 and 48 responded Student 41 : (We practice every weekend kapag may mga gagawin kami sa school na activities but I feel worried if there is something happened on me) (We practice every weekend when we do activities in school but I feel worried if there is something happened on me] and Student 48: (Hindi talaga ako maka-focus sa pag-aaral sa tuwing maaalala ko ang bakbakan na naganap sa Marawi City) (I cannot really focus on learning every time I remember the fight that took place in Marawi City].

According to McLeod (2008), forgetting is a result of interferences - such as the interference brought about by stressors. At times, forgetting is an effect of any traumatic experiences because the trauma may have interfered largely in the retrieval of information.

All other anxiety indicators revealed to be rated as low and very low, which implies that the student does not have any physical complaints such as muscle tensions, excessive sweating, 
trembling, and sleeping problems. The students also noted that even when anxiety is present, the students resiliently fought back by doing their school responsibilities daily.

Table 4: Chi-square test results on psychological status and academic performance in science after the Marawi siege

\begin{tabular}{|c|c|c|c|c|}
\hline $\begin{array}{l}\text { Variables } \\
\text { Pearson Chi-square }\end{array}$ & $\mathrm{df}$ & Chi-square & $P$ value at $\alpha=0.05$ & Interpretation \\
\hline $\begin{array}{l}\text { Anxiety and Stress } \\
\text { manifestation }\end{array}$ & & & & \\
\hline without psychosocial intervention & 6 & 3.793 & 0.705 & Not significant \\
\hline with psychosocial intervention & 8 & 15.933 & 0.043 & Significant \\
\hline $\begin{array}{l}\text { Stress } \\
\text { without psychosocial intervention } \\
\text { with psychosocial intervention }\end{array}$ & $\begin{array}{c}12 \\
16\end{array}$ & $\begin{array}{l}9.921 \\
24.147\end{array}$ & $\begin{array}{l}0.623 \\
0.009\end{array}$ & $\begin{array}{l}\text { Not significant } \\
\text { Significant }\end{array}$ \\
\hline $\begin{array}{l}\text { Anxiety } \\
\text { without psychosocial intervention } \\
\text { with psychosocial intervention }\end{array}$ & $\begin{array}{c}12 \\
16 \\
\end{array}$ & $\begin{array}{c}14.135 \\
24.147 \\
\end{array}$ & $\begin{array}{l}0.292 \\
0.086 \\
\end{array}$ & $\begin{array}{l}\text { Not significant } \\
\text { Not significant }\end{array}$ \\
\hline
\end{tabular}

It can be seen in Table 4, the chi-square test results on psychological status and academic performance of the students after the Marawi siege. From the table, it can be implied that before the psychosocial intervention the psychological status of the student does not significantly influence the academic performance in science. This means that the students are unaware of the real situations on the effect of the siege may be because their parents, relatives are ready to help and support them emotionally and mentally.

Student 20: (The true is there's nothing that affects to my academic especially in science, you can say that I have a strong mentality, but really, I didn't affect at all because of my family support) and Student 55: (Honestly nothing has changed because I'm not very affected for what happening in Marawi and it didn't affect my academic performance in science subject or even the other subjects because I already move on from that). In contrast to these findings, it was revealed that academic anxiety strongly affects the performance of the students at school (Dobson, 2012). After the psychosocial intervention, the results of the stress and anxiety manifestation and stress are significant with the academic performance of the students in science except for the anxiety toward the academic performance. This implies that psychosocial intervention helps them to recover from stress and anxiety manifestation.

Nakalema \& Senyonga (2013) findings showed that daily academic hassles were found to be the most stressful, while personal problems were reported as the least stressful. Also, a stressed person may not be able to function effectively. For students, stress can have a very significant impact on their academic endeavor (Lumontod III, 2017). Moreover, academic stress occurs under four circumstances: when student do not have the motivation to their tasks; when responsibilities are overwhelming; and when school environment in itself is a stressor; and when the student is disturbed by personal adverse experiences (Ader \& Erktin, 2002).

\section{Conclusions}

Based on the findings of the study, the following conclusions are presented;

1. The relationship between the psychological status (anxiety and stress manifestation, stress, and anxiety levels) and their academic performance in science of the students after the Marawi siege without psychosocial intervention was not significant.

2. The relationship between the psychological status (anxiety and stress manifestation, and stress levels) and their academic performance in science of the students after the Marawi siege with psychosocial intervention was significant. Hence, the anxiety level and their academic performance were not significant. 


\section{References}

Ader, E., \& Erktin, E. (2010). Coping as self-regulation of anxiety: Model for math achievement in highstakes tests. Cognition, Brain, Behaviour an Interdisciplinary Journal, 14(1), 311-332.

PSA. (2015). Census of Population, ARMM - Autonomous Region in Muslim Mindanao.

Dobson, C. (2012). Effects of Academic Anxiety On The Performance of Students With And Without Learning Disabilities And How Students Can Cope With Anxiety At School (Published Master's Thesis), Northern Michigan University. Retrieved from https://www.nmu.edu/education/sites/DrupalEducation/files/UserFiles/Dobson_Cassie_MP.pdf.

Gita, R. (2017). Duterte declares liberation of Marawi. Sun Star, Philippines. Retrieved from https://www.sunstar.com.ph/article/169781.

Gotttesman, A. (2016). How does violent conflict affect education? BORGEN Magazine. Retrieved from https://www.borgenmagazine.com/violent-conflict-afect-education/.

Knudson, P. (2017). Sources of strength promotes culture of caring in schools. Retrieved from http://www.grandforksherald.com/news/4342218-sources-strength-promotes-culture-caringschools.

Lumontod, R. (2017). The effect of stress on student academic performance. Psych Lens. Retrieved from https://psychlens.com/effect-of-stress-on-students/.

McLeod, S. (2008). Forgetting. Simply psychology. Retrieved from https://www.simplypsychology.org/forgetting.html.

Nakalema, G., and Senyonga, J. (2014). Academic stress: Its causes and results at a Uganda University. AJOTE African Journal of Teachers Education, 3(3).

Torres, W. (nd). RIDO clan feuding and conflict management in Mindanao. Ateneo De Manila. University Press, Expanded Edition. 